\title{
Unusual Presentation of Miliary Tuberculosis
}

${ }^{1}$ Division of Pulmonary Medicine, Eulji University School of Medicine, ${ }^{2}$ Division of Pulmonary Medicine, Chungnam National University, ${ }^{3}$ Internal Medicine, Sun General Hospital, Daejeon, Korea

Kyoung Tae Ko, M.D. ${ }^{3}$, Dong Jib Na, M.D. ${ }^{1}$, Sang Hoon Han, M.D. ${ }^{3}$, Sung Soo Jung M.D. ${ }^{2}$,

Kyoung Min Moon, M.D. ${ }^{1}$, Dong Jin Kim, M.D. ${ }^{1}$, Yang Deok Lee, M.D. ${ }^{1}$, Yong Seon Cho, M.D. ${ }^{1}$, Min Soo Han, M.D. ${ }^{1}$

\section{드문 형태의 속립성 결핵}

고경태 ${ }^{3}$, 나동집 ${ }^{1}$, 한상훈 $^{3}$, 정성수 $^{2}$, 문경민 $^{1}$, 김동진 ${ }^{1}$, 이양덕 $^{1}$, 조용선 ${ }^{1}$, 한민수 $^{1}$

${ }^{1}$ 을지의과대학교 호흡기내과, ${ }^{2}$ 충남대학교 의과대학 호흡기내과, ${ }^{3}$ 대전 선병원 내과

결핵은 일차적으로 폐에 주로 발생하지만 혈행성 전파를 통하여 모든 기관에 나타날 수 있으며 면역 억제자의 경우 특히 가능성이 높다. 저자들은 평소 건강했던 속립성 폐결핵 환자에서 간, 비장, 신장, 뇌막 및 뇌실질에 동시에 나타난 다발성 결핵을 보고한다. (Tuberc Respir Dis 2007; 63: 67-71)

Key Words: Miliary tuberculosis, Multiorgan, Immunocompetent.

\section{INTRODUCTION}

Tuberculosis is a contagious bacterial disease that primarily involves the lungs and infrequently, intense systemic dissemination from the rupture of a Mycobacterium tuberculosis-laden focus into a vascular channel results in miliary tuberculosis.

Miliary tuberculosis accounts for about 1-2\% of all cases of tuberculosis and about $8 \%$ of all forms of extrapulmonary tuberculosis in immunocompetent individuals ${ }^{1,2}$. It usually occurs in HIV infection, malignancy, immunosuppressive therapy, chronic renal failure, malnutrition, and chronic alcoholism ${ }^{3}$.

We observed an unusual form of miliary tuberculosis who presented with multiorgan involvement including liver, spleen, kidney, meninges, and brain in immunocompetent patient.

Address for Correspondence: Dong Jib Na, M.D. Division of Pulmonary Medicine, Department of Internal Medicine, Eulji University School of Medicine, 1036 Dunsan 2-dong, Seo-gu, Daejeon, 302-799, Korea. Phone: 82-42-611-3154, Fax: 82-42-611-3853

E-mail: djna13@gmail.com

Received: Apr. 20. 2007

Accepted: Jun. 14. 2007

\section{CASE REPORT}

An 18-year old girl was admitted to the hospital because of 2 weeks history of dry cough, fever, and headache. She was a healthy high school student and went on a fast 2 months ago. Clinical examination revealed a obese, slightly tachypneic patient with blood pressure of 110/70 mm Hg, temperature of $37.3^{\circ} \mathrm{C}$, heart rate of 104 beats/min, and respiratory rate of 26 breaths/min. She appeared ill but examination of the lung and heart was unremarkable. Abdominal examination revealed tenderness in right upper region without hepatosplenomegaly and left costovertebral tenderness. She also had neck stiffness upon neck flexion.

Laboratory data revealed the following: WBC count, $10,230 / \mathrm{mm}^{3}$ with neutrophil, $87 \%$ and $1 \mathrm{ym}-$ phocyte, 9\%; hemoglobin, $12.7 \mathrm{~g} / \mathrm{dl}$; hematocrit 36.8\%; albumin, $3.7 \mathrm{~g} / \mathrm{dl}$; AST, $48 \mathrm{IU} / \mathrm{L}$; ALT, 51 IU/L; alkaline phosphatase $157 \mathrm{IU} / \mathrm{L}$; total bilirubin, $2.3 \mathrm{mg} / \mathrm{dl}$ with direct bilirubin, $1.1 \mathrm{mg} / \mathrm{dl}$. A urinalysis showed 2 protein, 0 to $1 \mathrm{RBCs}$, and 2 to 3 WBCs per high-power field. Arterial blood gas analysis showed a $\mathrm{pH}$ of 7.51; $\mathrm{PaCO}_{2}, 27.4 \mathrm{~mm} \mathrm{Hg}$; $\mathrm{PaO}_{2}, 74.4 \mathrm{~mm} \mathrm{Hg}$; and oxygen saturation, 96.4\% 


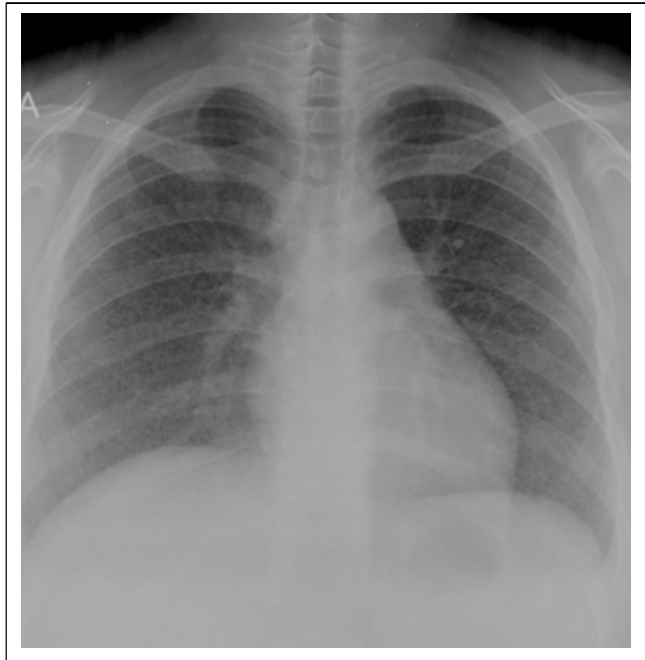

(A)

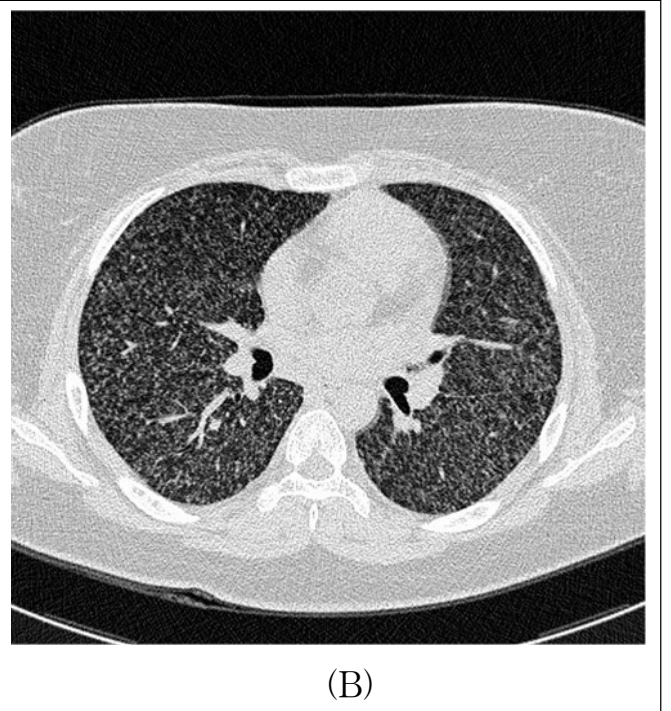

(B)

Figure 1. (A) Chest Radiograph shows fine nodular opacites bilaterally. (B) High Resolution CT shows numerous fine and discrete nodules bilaterally in a random distribution.

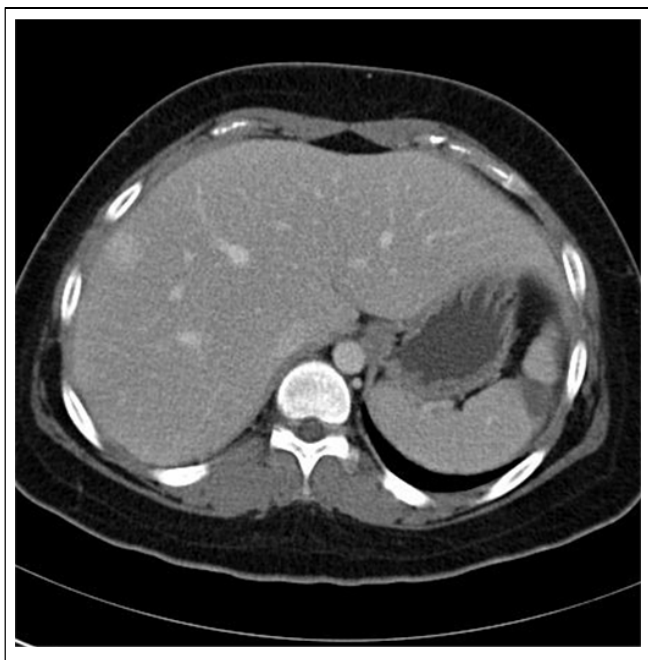

(A)

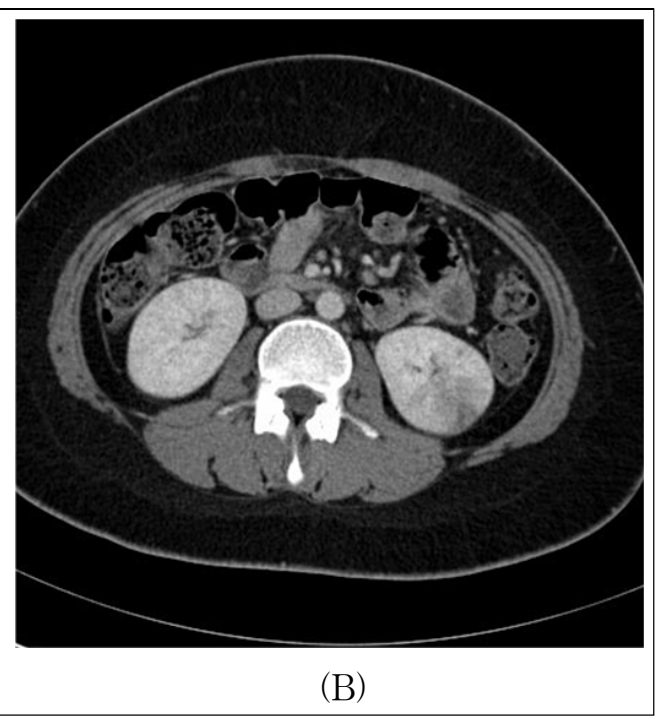

Figure 2. Abdomen CT shows an enhancing nodule within liver and a wedge-shaped low-attenuation lesion in spleen (A). At a slightly caudal level, a hypoattenuation lesion in left kidney (B).

while she was breathing ambient air. Tuberculin skin test and HIV serology were negative. Fundus examination was unremarkable.

Chest $\mathrm{X}$ ray (Figure 1A) and high-resolution thorax computed tomography (Figure 1B) were interpreted as a positive evidence for miliary tuberculosis. Abdominal CT (Figure 2) showed multiorgan involvement including liver, spleen, and kidney: ill defined enhancing lesion in liver; a peripheral wedge shaped low attenuation in upper area of spleen; an ill defined low attenuation in lower area of left kidney. Magnetic resonance imaging (Figure 3) of brain revealed multiple small enhancing nodules in cerebral hemispheres, right cerebellar hemisphere, left basal ganglia, brain stem, and letomeningeal enhancement of right parietal 


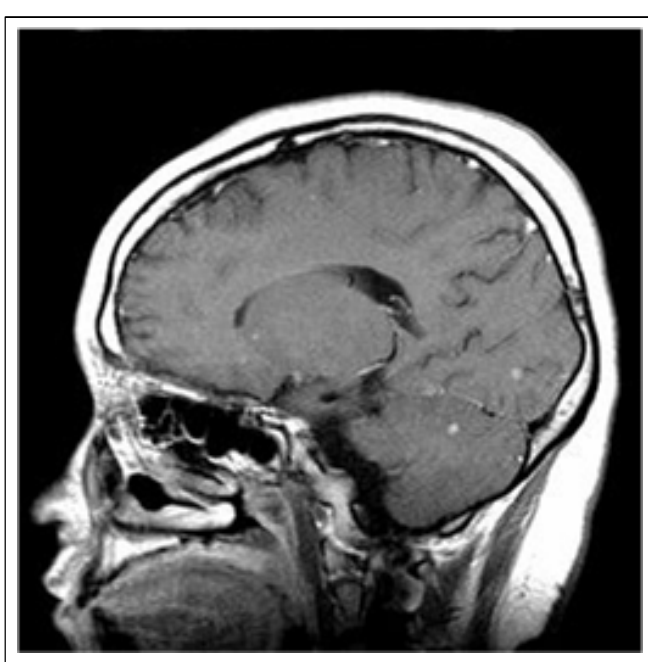

(A)

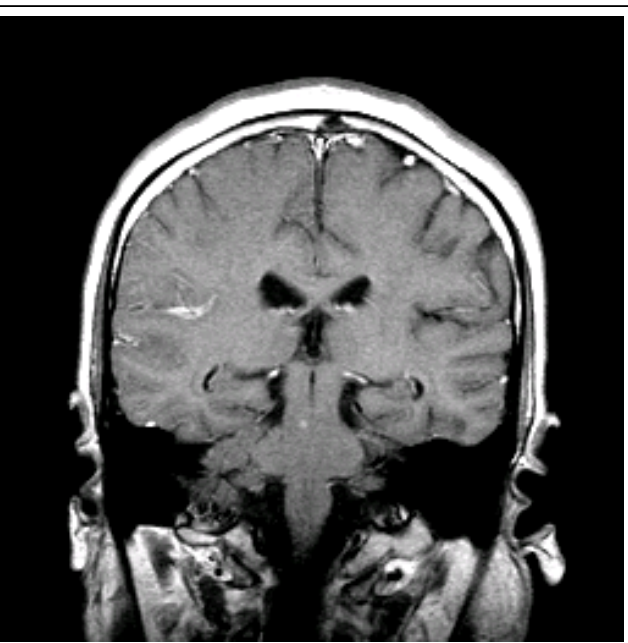

(B)

Figure 3. Brain MRI reveals multiple enhancing nodules in cerebral, celebellar hemisphere, basal ganglia (A), and brain stem $(B)$.

lone.

A lumbar puncture was performed. Cerebrospinal fluid (CSF) examination showed $300 \mathrm{WBC} / \mathrm{mm}^{3}$ with $80 \%$ neutrophils and 20\% lymphocytes, protein $57 \mathrm{mg} / \mathrm{dl}$, glucose $41 \mathrm{mg} / \mathrm{dl}$, and raised ADA level 9 IU/L. Sputum, CSF, and urine smears for Mycobacteria were negative. Her parent refused to have invasive biopsy procedure.

The patient was promptly started empirically on antituberculous therapy, with isoniazid, rifampin, ethambutol, pyrazinamide and combined with dexamethasone tapered over six weeks for meningitis. At a 2-month follow up, she had improved with gradual resolution of constitutional symptoms and fine infiltrations on chest radiography. Culture of sputum, CSF, and blood were negative for Mycobacterium tuberculosis. But Mycobacterium tuberculosis was isolated only in a urine culture.

At 5 months after antituberculous treatment she was well. Repeated abdomen CT revealed resolution of previous abnormal findings in liver, but an increase in the size of spleen with multiple hypoattenuating lesions of spleen and both kidney. Follow up Brain MRI also showed aggravating nodules in frontotemporal area with improving of previous nodules in cerebral and cerebellar hemisphere. She was referred to another teaching hospital for further evaluation. US-guided aspiration of spleen was then performed instead of more invasive brain biopsy. Histological result was characterized by caseating granulomatous inflammation consistent with tuberculosis. She continued to improve on the same antituberculous treatment, which was stopped after 12 months.

\section{DISCUSSION}

Miliary tuberculosis is a potentially lethal form of tuberculosis resulting from massive hematogenous dissemination of Mycobacterium tuberculosis bacilli. At autopsy, organs with high blood flow are frequently affected in miliary tuberculosis: spleen, liver, lungs, bone marrow, kidneys, and adrenals.

Clinical manifestations of miliary tuberculosis are nonspecific and protean, depending on the predo- 
minant site of involvement. Fever, night sweats, anorexia, weakness, and weight loss are presenting symptoms in the majority of cases. At times, patients have a cough and other respiratory symptoms due to pulmonary involvement as well as abdominal symptoms. Physical findings include hepatomegaly, splenomegaly, and lymphadenopathy.

Hepatic granulomas are present in more than 90 percent of patients with miliary tuberculosis, approximately 70 percent of those with extrapulmonary tuberculosis ${ }^{4}$. Serum aminotransferases may be minimally elevated and jaundice is rare. Splenic involvement is very rare and is usually associated with miliary dissemination, and involvement of the liver is quite frequent ${ }^{5,6}$. CT image of splenic tuberculosis usually demonstrates small multiple hypoattenuating lesions and splenomegaly $^{7}$. Final diagnosis was made by laparotomy, although CT guided splenic puncture is becoming a more ideal and popular method nowadays ${ }^{8}$.

Tuberculosis of the urinary tract is easily overlooked. Suspicions of tuberculosis are aroused only when there is no response to the usual antibacterial agents or when urine examination reveals pyuria in the absence of a positive culture on routine media ${ }^{9}$. The kidney is frequently involved in miliary tuberculosis where blood-borne miliary tubercles are seen throughout the renal substance, most noticeably in the cortex. Organisms can be usually demonstrated microscopically within these lesions but sometimes are difficult to find. Renal function is not usually compromised in these patients $^{9}$.

Central nervous system(CNS) disease such as meningitis or tuberculoma is suggested clinically in 15 to 20 percent of patients ${ }^{10}$. In a study, all 20 patients with miliary tuberculosis had meningitis and on MRI 7 patients had miliary tuberculoma ${ }^{11}$. The prognosis of miliary tuberculosis is linked to age, immune status and multiorgan involvement but CNS involvement has been reported as an independent predictor of mortality.

Treatment guidelines state that 6 months of treatment adequate in miliary tuberculosis ${ }^{12}$. In the presence of associated tuberculosis meningitis, treatment needs to be given for at least 12 months ${ }^{12}$. Adjunctive corticosteroid treatment may be beneficial in miliary tuberculosis with tuberculosis meningitis, large pericardial or pleural effusion ${ }^{13}$.

On follow up abdominal CT and brain MRI in the presented case, aggravating findings of spleen, kidney, and brain lesion were thought to be a transient paradoxical worsening of tuberculosis. Discussion concerning the mechanism of this entity is still controversial. The most likely explanation is interplay between the host's immune responses and the direct effects of mycobacterial products ${ }^{14}$. Antituberculous drugs cause destruction of mycobacterial structures and liberation of bacillary proteins that provoke a delayed hypersensitivity immune reaction. In accordance with the previously reported cases in literature, we also believe in that CNS tuberculoma enlargement does not necessitate changes in the administered antituberculous drugs, but requires prolonged treatment ${ }^{15}$.

\section{CONCLUSION}

In this case, involvement in many tissues such as hepatic, spleen, kidney, meninges, and brain were seen, and these finding is an unusual presenting feature of miliary tuberculosis in immunocompetent patient.

\section{REFERENCES}

1. Rieder HL, Snider DE Jr, Cauthen GM. Extrapulmonary tuberculosis in the United States. Am Rev 
Respir Dis 1990;141:347-51.

2. Long R, O’Connor R, Palayew M, Hershfield E, Manfreda J. Disseminated tuberculosis with and without a miliary pattern on chest radiograph: a clinical-pathologic-radiologic correlation. Int J Tuberc Lung Dis 1997;1:52-8.

3. Hill AR, Premkumar S, Brustein S, Vaidya K, Powell $\mathrm{S}$, Li PW, et al. Disseminated tuberculosis in the acquired immunodeficiency syndrome era. Am Rev Respir Dis 1991;144:1164-70.

4. Klatskin G. Hepatic granulomata: problems in interpretation. Mt Sinai J Med 1977;44:798-812.

5. Jain A, Sharma AK, Kar P, Chaturvedi KU. Isolated splenic tuberculosis. J Assoc Physicians India 1993; 41:605-6.

6. Gulati MS, Sarma D, Paul SB. CT appearances in abdominal tuberculosis. A pictorial essay. Clin Imaging 1999;23:51-9.

7. Radin DR. Intraabdominal Mycobacterium tuberculosis vs Mycobacterium avium-intracellulare infections in patients with AIDS: distinction based on CT findings. AJR Am J Roentgenol 1991;156:487 - 91.

8. Adil A, Chikhaoui N, Ousehal A, Kadiri R. Splenic tuberculosis. Apropos of 12 cases. Ann Radiol (Paris) 1995;38:403-7.

9. Eastwood JB, Corbishley CM, Grange JM. Tuber- culosis and the kidney. J Am Soc Nephrol 2001; 12:1307-14.

10. Maartens G, Willcox PA, Benatar SR. Miliary tuberculosis: rapid diagnosis, hematologic abnormalities, and outcome in 109 treated adults. Am J Med 1990;89:291-6.

11. Kalita J, Misra UK, Ranjan P. Tuberculous meningitis with pulmonary miliary tuberculosis: a clinicoradiological study. Neurol India 2004;52:194-6.

12. Blumberg HM, Burman WJ, Chaisson RE, Daley CL, Etkind SC, Friedman LN, et al. American Thoracic Society/Centers for Disease Control and Prevention /Infectious Diseases Society of America: treatment of tuberculosis. Am J Respir Crit Care Med 2003;167: 603-62.

13. Baker SK, Glassroth J. Miliary tuberculosis. In: Rom WN, Garay SM, eds. Tuberculosis. Philadelphia: Lippincott Williams \& Wilkins; 2004. p. 427-44.

14. Afghani B, Lieberman JM. Paradoxical enlargement or development of intracranial tuberculomas during therapy: case report and review. Clin Infec Dis 1994;19:1092-9.

15. Hejazi N, Hassler W. Multiple intracranial tuberculomas with atypical response to tuberculostatic chemotheraphy: literature review and a case report. Infection 1997;25:233-9. 